\title{
Law Enforcement against Narcotics Crime through Rehabilitation in a Restorative Justice Perspective
}

\author{
Adrian $^{1 *}$, Andi Muhammad Sofyan ${ }^{2}$, Abd. Asis ${ }^{3}$, Wiwie Heryani ${ }^{4}$ \\ ${ }^{1}$ Doctoral Student, Faculty of Law, Hasanuddin University, Makassar, Indonesia \\ ${ }^{2}$ Professor, Faculty of Law, Hasanuddin University, Makassar, Indonesia \\ ${ }^{3,4}$ Associate Professor, Faculty of Law, Hasanuddin University, Makassar, Indonesia
}

DOI: $10.36348 /$ sijlcj.2021.v04i04.003

| Received: 22.02.2021 | Accepted: 09.04.2021 | Published: 15.04.2021

*Corresponding author: Adrian

\section{Abstract}

Rehabilitation arrangements for narcotics abuse users in Indonesia have been regulated in Law Number 35 Year 2009 concerning Narcotics. The relevant law describes the function of rehabilitation, but does not specify the categories that are eligible to receive rehabilitation facilities. The elaboration regarding the requirements for receiving the rehabilitation facility is only spelled out in the Supreme Court Circular Letter Number 04 Year 2010. This in turn can lead to wrong actions against narcotics abusers. The implementation of medical and social rehabilitation for narcotics abusers in Indonesia has begun to be improved. This can be seen from the improvement in the quality standards of the rehabilitation facilities, as well as the efforts to strengthen rehabilitation institutions. Referring to the ideal concept of implementing rehabilitation for narcotics abuse users in the perspective of restorative justice, rehabilitation of narcotics abusers must be provided. In this case there are two rehabilitation processes that must be provided, namely medical rehabilitation and social rehabilitation. Medical rehabilitation to restore abusers from dependence, while social rehabilitation so that narcotics abusers can be accepted back into society.

Keywords: law enforcement, narcotics crime, rehabilitation, restorative justice perspective.

Copyright (C) 2021 The Author(s): This is an open-access article distributed under the terms of the Creative Commons Attribution 4.0 International License (CC BY-NC 4.0) which permits unrestricted use, distribution, and reproduction in any medium for non-commercial use provided the original author and source are credited.

\section{INTRODUCTION}

Crime is a classic problem of humankind in its social environment so that by Benedict A. Alper termed crime is the oldest social problem [1]. In the effort to tackle crime or it is also known as "criminal politics" according to G.F. Heofnagels can be reached in three ways, namely [2]:

a. Criminal law application;

b. Prevention without punishment; and

c. Influencing views of society on crime and punishment/mass media.

Therefore, international cooperation efforts are needed to fight drug-related crimes [3]. The problem of narcotics has become a global problem, so that various international conventions have been created, one of which is: Single Convention on Narcotic Drugs, 1961 which was later changed to Procotocol Amending the Single Convention on Narcotic Drugs, 1961, followed by Convention on Psychotropic Substance, 1971, and finally is the United Nations Convention Against Illicit Traffic in Narcotic Drugs and Psychotropic Substances,
1988[4]. In line with global policies, the legal policy of the Indonesian Government which is the country's legal policy in handling narcotics crimes is to position narcotics users as perpetrators of serious crimes, in this case users must be seen as victims, however in practice, the human rights of narcotics users have been abused, in Article 127 of the Law of the Republic of Indonesia Number 35 Year 2009 concerning Narcotics (the Narcotics Law), should have received rehabilitation, or at least received a lighter sentence, but its implementation in the field of users is actually subject to Article 112 of the Narcotics Law, even subject to Article 114 of the Narcotics Law, which should be imposed by dealers or dealers. Narcotics dealers must be considered the party who committed serious crimes, while Article 127, does not apply to narcotics users so that narcotics users lose their constitutional rights to be rehabilitated.

Providing adequate medical and legal assistance, a fair examination and trial process for criminals, is basically a manifestation of the protection of human rights as well as a balancing instrument [5]. 
Adrian et al., Sch Int J Law Crime Justice, Apr, 2021; 4(4): 205-211

The practice of law enforcement for the crime of narcotics puts forward punishment rather than healing, so that narcotics users end up imprisoned, while the health dimension through rehabilitation is less paid attention to and even tends to be ignored. Even though the punishment for narcotics users has been affirmed by being given a rehabilitation sentence for narcotics users if no evidence is found as narcotics traffickers, the legal fact is that some narcotics users have been criminalized by law enforcers. The penalties should be differentiated for narcotics users and dealers, narcotics users and addicts simply undergo a medical and social rehabilitation process, but some of them even end up in prison even though it is clearly and firmly regulated in Article 128 of the Narcotics Law that drug users undergo medical rehabilitation. Obliged not to be prosecuted criminal, whereas in fact the majority of rehabilitation participants are still convicted.

In prison the perpetrator will continue to try to meet the needs of dependence on narcotics so that he will do various ways to fulfill his dependence. This can be proven by the rampant trafficking of narcotics in prisons [6]. An example of a case studied by Alamsyah Rustam, a BTN Barombong Indah resident, Kalabbirang Village, Pattallasang District, Takalar Regency, which based on Decision Number 64/Pid.Sus/2019/PN.Tka has violated Article 127 paragraph (1) letter a of the Narcotics Law and was sentenced to for 2 years in prison. Is Alamsyah a dealer or a user for himself? If Alamsyah acts as a user, why is Alamsyah detained in the law enforcement process? Is it not in the law enforcer's obligation to carry out investigations, prosecutions and rehabilitative trials of cases of abusers for themselves.

Drug users, apart from being the perpetrators, are also victims of these crimes. The concept of regulating the protection of victims of criminal acts, the first thing that must be considered is the essence of the harm suffered by the victim. The essence of the loss is not only material or physical suffering but also psychological in nature[7]. The definition of victim is defined in the narrow sense as victim of crime, namely victims of crime as stipulated in the provisions of criminal law [8]. A person who has suffered harm as a result of a crime and or whose sense of justice has been directly impaired as a result of his experience as the target of a crime [9]. The suffering he experiences is mental, physical, material, and immaterial [10]. Thus, in the protection of crime victims, there are 2 (two) models of protection, namely the procedural rights model and the services model [11].

It is hoped that the Criminal Procedure Code can serve as a guideline for conducting justice for courts within the domain of the general court and the Supreme Court by regulating the rights and obligations of those in the criminal process, so that the basis of the rule of law can be upheld [12]. The manifestation of law supremacy through restorative justice is essentially the realization of a law enforcement process (justice) which is oriented towards restoring the relationship to the original state (restorative), not justice which is only oriented towards retribution (retributive and not justice oriented only to recovery of losses). The implementation of the principles of restorative justice in the settlement of cases outside the court should be carried out by prosecutors through termination of prosecution in the public interest based on the principle of opportinity, because prosecutors are pseudo judges [13]. Rehabilitative law enforcement such as the Alamsyah case is based on the provisions in Article 54 of the Narcotics Law that "users and addicts are guaranteed to get rehabilitation efforts, both medical rehabilitation and social rehabilitation".

Juridically, if Alamsyah is a user for himself, Alamsyah must undergo a law enforcement process without detention because the case of narcotics users does not meet the requirements for detention due to the rehabilitative nature of law enforcement. Therefore narcotics investigators are obliged to place Alamsyah in a designated hospital, such as General Hospital $\mathrm{H}$. Pajonga Dg. Ngale Takalar. Based on the authority given by narcotics investigators based on Article 13 of Government Regulation No. 25 Year 2011 concerning the Implementation of the Mandatory Report for Narcotics Addicts.

Based on Article 54 of the Narcotics Law, states that the narcotics user is a victim, this is indicated by the provision that a drug user and addict can be sentenced to a rehabilitation sentence, unless Alamsyah can be proven as a dealer, or possession of narcotics for sale with the aim of obtaining profit, then Alamsyah legally and fulfills the requirements for forced attempts by narcotics investigators in the form of detention. The prosecution of the Alamsyah case and other user cases are rehabilitative in nature, for example Alamsyah was sentenced to rehabilitation, so the public prosecutor based on Article 4 of the Narcotics Law specifically loses the right to appeal even though it is charged with imprisonments

In 2010 the Supreme Court issued Supreme Court Circular (Surat Edaran Mahkamah Agung/SEMA) No. 4 Year 2010 concerning Placement of Abuse, Abuse Victims and Narcotics Addicts into Rehabilitation Institutions, hereinafter abbreviated as SEMA No. 4 Year 2010, which is a guide for judges to decide rehabilitation decisions. SEMA No. 4 Year 2010 states five conditions for obtaining a rehabilitation decision, namely: 1) the defendant was caught redhanded; 2) at the time of being caught red-handed, one day of use evidence is found (attached to the SEMA); 3 ) positive laboratory test letter using narcotics; 4) a certificate from a psychiatrist/psychiatrist; and 5) not proven to be involved in the trafficking of narcotics. 
Adrian et al., Sch Int J Law Crime Justice, Apr, 2021; 4(4): 205-211

Legal regulations related to drug addicts, users and abusers refer to the Narcotics Law and Government Regulation No. 25 Year 2011 concerning the Mandatory Reporting of Narcotics Addicts, then addicts or users and victims of Narcotics abuse are required to undergo medical rehabilitation and social rehabilitation.

Article 54 of the Narcotics Law stipulates that narcotics addicts and victims of narcotics abuse are required to undergo medical rehabilitation and social rehabilitation. This has also been confirmed and regulated in more detail in the Government Regulation No. 25 Year 2011. In addition, Article 3 paragraph (1) of the Regulation of the Head of the National Narcotics Agency Number 11 Year 2014 concerning Procedures for Handling Suspects and/or Accused Narcotics Addicts and Victims of Narcotics Abuse into Rehabilitation Institutions (BNN Regulation No. 11 Year 2014) regulates that Narcotics Addicts and Victims of Narcotics Abuse who are without rights and against the law as suspects and/or defendants in Narcotics abuse who are undergoing the process of investigation, prosecution, and trial in court are given treatment, care and recovery in a rehabilitation institution. Likewise SEMA No. 4 Year 2010 to reuse Article 103 of the Narcotics Law, which states that judges can decide drug addicts to undergo rehabilitation.

So far, law enforcement officials still view the Narcotics Law as oriented towards imprisoning drug users/addicts, so that they are considered criminals. In fact, the year 2014 has been proclaimed by the government as the year to save victims of drug abuse through rehabilitation.

In an effort to change the paradigm of criminalizing drug users from the Attorney General's Office, the Police, the Ministry of Law and Human Rights, Supreme Court, the Ministry of Social Affairs, the Ministry of Health signed the 2014 Joint Regulation on the Rehabilitation of Narcotics Addicts. Through this regulation, if a person is arrested by the National Police or BNN investigators of using or possessing narcotics, they will still be legally processed under the charges of Article 127 of the Narcotics Law, whose verdict imposes an order for rehabilitation. As for Article 127 of the Narcotics Law, the punishment is under 5 years, so there is no need to be detained.

The determination of whether he is rehabilitated or not remains through a court decision. This is regulated in Article 127 paragraph (3) of the Narcotics Law which states that in the event that an Abuser can be proven or proven to be a victim of Narcotics abuse, the Abuser is obliged to undergo medical rehabilitation and social rehabilitation. The factors that significantly influence the judge in delivering rehabilitation decisions are medical certificates, psychiatric certificates from psychiatrists and the presence of experts.

Even though it is still in the criminal justice process, whether it is an investigation, prosecution, or trial hearing in court; without waiting for the judge's decision; An investigator, public prosecutor or judge may request an assessment of a suspect or defendant before being placed in a rehabilitation institution.

The Institute for Criminal Justice Reform (ICJR) notes, in Reviewing the Rehabilitation of Narcotics Users in Judicial Practice, the view of narcotics users as criminals is still more dominant than the health and healing approach to narcotics dependence. A number of articles in the Narcotics Law are often imposed by public prosecutors, both in the indictment and indictment, both from Article 111, Article 112, Article 114, and Article 127 of the Narcotics Law.

\section{RESEARCH METHOD}

This type of research is a sociojuridical research using a conceptual approach, a historical approach, and a case approach. The data used are primary data obtained directly from the research field, and secondary data consisting of primary legal materials, secondary legal materials, and non-legal materials. The collected data were then analyzed qualitatively [14].

\section{RESULTS AND DISCUSSION Rehabilitation Regulations in Indonesia}

When the perpetrator of a crime has been sentenced to a criminal sanction by the court, the condition of the crime victim seems to be completely ignored. In fact, the issue of justice and respect for human rights does not only apply to criminals, but also victims of crime [15]. In connection with the policy direction of the National Narcotics Agency related to the rehabilitation of addicts and Narcotics users, an achievement strategy is established through the development of integrated and sustainable access to rehabilitation services for abusers, victims of abuse, and narcotics addicts, as well as optimizing the role of ministries or institutions in the use of infrastructure and ministry or agency resources.

Montesquieu argued that good legislation should emphasize crime prevention rather than punishment [16]. In accordance with the realization and performance achievements of the National Narcotics Agency in 2018, in terms of increasing efforts to recover narcotics addicts through comprehensive and sustainable rehabilitation services, the number of rehabilitation facilities nationally that have met minimum service standards is 152 facilities, while the number of abusers and/or narcotics addicts nationwide who recovered as many as 2,660 people [17]. Of the 152 national rehabilitation facilities, consisting of 84 
Adrian et al., Sch Int J Law Crime Justice, Apr, 2021; 4(4): 205-211

rehabilitation facilities for government agencies, 68 rehabilitation facilities for community components are calculated accumulatively [18]. There are also a number of rehabilitation facilities belonging to government agencies and community components that have not met the minimum service standards, but continue to be given increased capacity, in order to achieve the minimum service standard of 904 facilities and as many as 665 rehabilitation facilities belonging to government agencies and operational community components [19].

Regulations for medical and social rehabilitation of addicts and victims of narcotics abuse are regulated in Narcotics Law. The provisions of medical rehabilitation for narcotics addicts are regulated in Article 1 number 16 of the Narcotics Law which emphasizes that Medical Rehabilitation is a process of integrated treatment activities to free addicts from narcotics dependence. Meanwhile, social rehabilitation in accordance with the provisions of Article 1 number 17 of the Narcotics Law is Social Rehabilitation is a process of integrated recovery activities, both physically, mentally and socially, so that former Narcotics addicts can return to carry out social functions in community life.

The distortion of legal thinking with the loss of legal integrity causes the law to feel unable to become a means of product of justice, the components of the legal apparatus have not been able to become producers of justice (jusctice producer), this is because the producers of legislation are unable to deliver justice as a spirit of legislation, and law enforcers. He does not have high moral integrity [20]. According to Satjipto Rahardjo, legal thinking needs to return to its basic philosophy, namely law for humans [21].

The implementation of medical rehabilitation and social rehabilitation for narcotics addicts is the goal of the establishment of the Narcotics Law as mandated in Article 4 letter d, which guarantees the regulation of medical and social rehabilitation efforts for abusers and narcotics addicts. In this regard, the implementation of medical rehabilitation and social rehabilitation for addicts and victims of narcotics abuse is an obligation that must be given to addicts and victims of narcotics abuse as described in Article 54 of the Narcotics Law. Specifically with regard to the implementation of medical rehabilitation and social rehabilitation for addicts and victims of narcotics abusers which are carried out based on a court decision, it is regulated in Article 127 paragraph (3) of the Narcotics Law which confirms that in the case of abusers as referred to in paragraph (1) can be proven or proven to be a victim of narcotics abuse, the abuser is obliged to undergo medical rehabilitation and social rehabilitation.

The provisions of Article 127 paragraph (3) of the Narcotics Law merely provide legal protection for addicts and victims of narcotics abuse to obtain medical rehabilitation and social rehabilitation, if proven to have committed narcotics abuse. Legal protection for narcotics addicts who are undergoing rehabilitation are given the right to legal immunity not to be prosecuted as regulated in Article 128 paragraph (3) of the Narcotics Law, namely Narcotics Addicts who are old enough as referred to in Article 55 paragraph (2) who are currently undergoing medical rehabilitation two times of doctor treatment in hospitals and medical rehabilitation institutions appointed by the government are not prosecuted.

The provisions of Article 103 paragraph (1) of the Narcotics Law confirm that the Judge examining the Narcotics addict case can: (a) decide to order the person concerned to undergo treatment or treatment through rehabilitation if the Narcotics Addict is found guilty of committing a Narcotics crime; or (b) determine to order the person concerned to undergo treatment and treatment through rehabilitation. If the Narcotics addict is not proven guilty of committing the crime of Narcotics. The provisions of Article 103 paragraph (1) of the Narcotics Law as mentioned above, provide confirmation that narcotics addicts are either convicted of committing Narcotics crimes or those who are not proven guilty of committing Narcotics crimes for medical rehabilitation and social rehabilitation.

If the Narcotics Addict is subject to punishment, then in accordance with the provisions of Article 103 paragraph (2) of the Narcotics Law, it is stated that the period of undergoing treatment or treatment for Narcotics Addicts is counted as the period of serving a sentence.

Moeljatno's formulation indicates that criminal law is a set of rules regulating three elements, namely rules regarding criminal acts, criminal liability and verbal process of law enforcement in the event of a criminal act. This element shows the relationship between material criminal law and formal criminal law, which means that violations of material criminal law will be meaningless without the enforcement of formal criminal law (criminal procedural law). Likewise, the formal criminal law cannot function without violating the norms of material criminal law (criminal acts) [22]. As a form of the government's political will in protecting addicts and victims of narcotics abuse, the government provides space for perpetrators or their families to report to community health centers, hospitals and medical rehabilitation and social rehabilitation institutions appointed by the Government to get treatment and care through rehabilitation. Medical and social rehabilitation.

Provisions related to the obligation to report themselves or be reported by addicts' families to carry out medical rehabilitation and social rehabilitation are regulated through Government Regulation Number 25 Year 2011 concerning the Implementation of 
Adrian et al., Sch Int J Law Crime Justice, Apr, 2021; 4(4): 205-211

Mandatory Reporting for Narcotics Addicts. Reporting is carried out by Narcotics Addict's parents or guardians who are not yet old enough, while for addicts who are old enough, Narcotics Addicts who are old enough or their families are done.

To get rehabilitation services, it is necessary to apply for rehabilitation. We conclude that the request for rehabilitation in court is submitted to the prosecutor (prosecution level) or judge (examination level). We have stated the requirements for the application above. Then, after that the Public Prosecutor for the benefit of prosecution and the Judge for the purposes of examination at court proceedings, may request assistance from the local Adjunct Assessment Team to assess the Defendant. So, it is the Public Prosecutor or Judge who asks for help to first assess the defendant. This assessment assistance is carried out based on this BNN Regulation 11/2014 and the results are submitted to the Public Prosecutor or Judge with the Minutes of submitting the assessment results recommendations. So, although the BNN Regulation No. 11 Year 2014 is basically a technical guideline for investigators (at the level of investigation) to request rehabilitation placement to a suspect/defendant after an assessment is carried out, at the level of prosecution or examination in court, prosecutors or judges can also request assessment from the Integrated Assessment Team. Whose procedures are based on the BNN Regulation No. 11 Year 2014.

\section{CONSTRAINTS ON REHABILITATION}

The rights of citizens to obtain protection are positive rights which in the sense that the state must actively and maximally fulfill its citizens [23]. The barriers and obstacles to rehabilitation for addicts and narcotics abuse are as follows [24]:

a. Constrained from the aspect of Biology is that narcotics users who want to be rehabilitated need a persuasive approach because, the client is not immediately interested in rehabilitation because his mind is disturbed, his heart and feelings are unstable because addictive substances have flowed throughout his organs, so that clients are no longer able to use them. rational sense;

b. Constrained Psychology takes a long time to normalize the hearts and souls of narcotics users;

c. Social is the stigma of society thinking that Rehabilitation is like laundry dirty clothes that must be washed clean.

The stages of the 6 month rehabilitation program are as follows [25]:

Medical examinations which include radiology, blood tests, examinations carried out by internists, for internal medicine, for approximately 2 weeks, Rehab in the intri unit stage, stabilization phase for approximately 1 month, primary phase for approximately 4 months, Re-entry phase or the socialization phase is approximately 1 month.
The TC (theraphy comunity) program is a group of people who have the same problem, they gather to help each other in overcoming the problems they face. In other words. Man helping man to help himself, that is someone helping others to help himself.

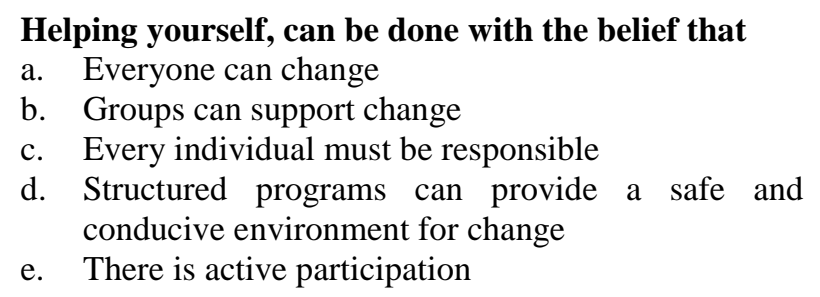

\section{TC program (theraphy comunity)}

a. Establishment of behavior or management of rehavil shappty

b. Emotional psychology

c. Intellectual and spiritual addicts are taught the understanding of religion every day

d. Vocational service is that addicts are taught skills according to their talents and abilities, so that after post-rehabilitation they can use their skills to make it easier to get a job.

\section{The last stage of rehabilitation (Self Evaluation)[26]}

a. The main plan is that the guidance counselor directs rehabilitation participants or postrehabilitation clients so that after completion of rehabilitation and adaptation in the community environment, it is clear what activities must be carried out in order to benefit themselves and their environment.

b. The long-term plan is the guidance counselor directs the client after rehabilitation, so that the client community can get a job or do activities that are beneficial to himself, his family and the environment.

In addition, regulations related to medical rehabilitation of addicts and victims of narcotics abuse are regulated in the Minister of Health Regulation No. 2415/MENKES/PER/ XII/2011 concerning Medical Rehabilitation of Addicts, Abusers and Victims of Narcotics Abuse. Related to the juridical basis in the issuance of Minister of Health Regulation No. 2415/MENKES/PER/XII/2011 concerning Medical Rehabilitation of Addicts, Abusers and Victims of Narcotics Abuse, it is based on the provisions of Article 59 paragraph (1) of the Narcotics Law and Articles 13 paragraph (6) Government Regulation No. 25 Year 2011.

Satjipto Raharjo's opinion on politics and law is that according to Sutjipto Raharjo that the law will be weak when faced with politics, so politics will always win when faced with the law. The consequence is that if the law is a law, then the law that will be made by the legislature will have a strong political aroma, compared to the benefits of the law for the attainment of justice 
Adrian et al., Sch Int J Law Crime Justice, Apr, 2021; 4(4): 205-211

and prosperity for the people. Judging from the expert's point of view, it is linked to Narcotics Law which was passed on September 14, 2009 as a revision of Law Number 22 Year 1997 concerning Narcotics. The government considers that Law No. 22 Year 1997 is no longer able to effectively prevent the crime of narcotics which is increasing both quantitatively and qualitatively, as well as the form of organized crime.

Substantially, significant changes to Law no. 35 of 2009 compared to the previous law, emphasizes the provision of rehabilitation obligations, the excessive use of crimes, and the enormous authority of the National Narcotics Agency. Basically, narcotics traffickers in legal terms are categorized as perpetrators (daders) but users can be categorized as either perpetrators and/or victims.

In the provisions of the Narcotics Law, users are regulated in Articles 116, 121, 126, 127, 128, 134 Forgetting victims of criminal acts cannot be released from criminal law in Indonesia which originates from the neo-classical criminal law which incidentally gave birth to criminal law that is "daad-dader strafrecht", namely criminal law that is oriented to the actions and perpetrators. The double track system is a two-track system regarding sanctions in criminal law, namely the types of criminal sanctions and action sanctions. Attention to criminal offenders who receive excessive protection, in the sense that it is not balanced with the interests of the victim, is a lame picture as a result of the criminal procedure law in Indonesia, which puts forward "fair legal process" or better known as the "due process model". Narcotics addicts are "Self Victimizing Victims", namely those who are victims of crimes they have committed themselves. A narcotics addict suffers from a dependency syndrome as a result of his own narcotics abuse. However, victims of narcotics abuse should receive protection so that the victim can become good.

The focus of criminal sanctions is aimed at wrongdoing that has been committed by a person through the imposition of suffering so that the person concerned becomes a deterrent. The focus of action sanctions is more focused on helping the perpetrator to change. It is clear that criminal sanctions emphasize more on retaliation while sanctions for action originate from the basic idea of community protection and guidance or care. Based on this, the double track system in the formulation of sanctions against the crime of narcotics abuse is the most appropriate, because based on victimology that narcotics addicts are selfvictimizing victims, namely victims as perpetrators, victimology still places narcotics abusers as victims, even though the criminal acts/crimes they commit alone.
Proving a narcotics abuser is a victim of narcotics as regulated in the Narcotics Law, is a difficult thing, because it has to see the first time a drug user uses narcotics and it is necessary to prove that a drug user when using narcotics is persuaded, tricked, cheated, forced and/or being threatened to use narcotics.

In its implementation, the Supreme Court issued a breakthrough by issuing Circular Letter Number 04 Year 2010 which became the reference for judges in deciding narcotics. Therefore, narcotics addicts who are also victims deserve protection. Narcotics addicts are also perpetrators of criminal acts/crimes so they must still be punished, because of this, it is said that the double track system in the formulation of sanctions against criminal acts of narcotics abuse is the most appropriate. The criminal sanctions imposed on narcotics addicts as selfvictimizing victims are in the form of serving time in prison, while the sanctions imposed on narcotics addicts as victims are in the form of treatment and/or treatment provided in the form of rehabilitation facilities. The implementation system is that the period of treatment or treatment is counted as a period of serving a sentence.

\section{CONCLUSION}

Rehabilitation arrangements for narcotics abusers in Indonesia have been regulated in the Narcotics Law, but the unclear regulations governing the differences between Narcotics users and/or addicts have resulted in the ineffective application of rehabilitation sanctions for Narcotics abusers. As in Articles 112 and 114 of the Narcotics Law, which does not clearly distinguish whether the article is intended for users or dealers, it only describes the categories of perpetrators who deserve to be punished. In this condition, law enforcers often use articles 112 and 114 of the Narcotics Law as a legal benchmark because they are easier to prove, while Article 127 of the Narcotics Law is rarely used, so narcotics users lose their constitutional right to be rehabilitated.

\section{REFERENCES}

1. Widiartana, V. (2014). Perspektif Korban dalam Penanggulangan Kejahatan, Yogyakarta: Cahaya Atma Pustaka, 55

2. Barda Nawawi Arief, S. H. (2018). Masalah penegakan hukum dan kebijakan hukum pidana dalam penanggulangan kejahatan. Prenada Media.

3. Thamrin, H., \& Liao, Y. M. (2018, August). DrugRelated Crimes and Control in Indonesia and Taiwan: Cooperation Regarding Narcotics Smuggling Prevention and Countermeasures from the Point of View of International Law. In International Conference on Knowledge Management in Organizations (pp. 312-323). Springer, Cham.

4. Iskandar, A. (2014). Dekriminalisasi Penyalah Guna Narkotika dalam Konstruksi Hukum Positif di Indonesia. 
5. M. Arief Mansur. (2007). Urgensi Perlidungan Korban Kejahatan Antara Norma dan Realita, Jakarta: PT. Raja Grafindo Persada, 161

6. Dwidja, P. (2006). Sistem Pelaksanaan Pidana Penjara di Indonesia. Refika Aditama, Bandung, 102.

7. Muladi. (1995). Kapita selekta sistem peradilan pidana. Badan Penerbit Universitas Diponegoro.

8. Mulyadi, L. (2010). Kompilasi hukum pidana dalam perspektif teoretis dan praktik peradilan: perlindungan korban kejahatan, sistem peradilan, dan kebijakan pidana, filsafat pemidanaan serta upaya hukum peninjauan kembali oleh korban kejahatan. Mandar Maju.

9. Arief, B. N., \& Arief, B. N. (1996). Bunga rampai kebijakan hukum pidana. Citra Aditya Bakti.

10. Waluyo, B. (2011). Viktimologi perlindungan korban \& saksi. Sinar Grafika.

11. Barda Nawawi Arief. (1998). Beberapa Aspek kebijakan Penegakan dan Pengembangan Hukum Pidana, Bandung: Citra Aditya Bakti, 58

12. Karim, M. S. (2019). Ganti Kerugian Terhadap Korban Penangkapan yang Tidak Sah dalam Proses Peradilan Pidana.

13. Andi, H. (2019). Hukum Acara Pidana Indonesia, Jakarta, Sinar Grafika, 206

14. Kadarudin. (2021). Penelitian di Bidang Ilmu Hukum (Sebuah Pemahaman Awal), Semarang: Formaci Press, 133
15. Mansur, D., \& Gultom, E. (2007). Urgensi Perlindungan Korban antara Norma dan Realita. Jakarta: Raja Grafindo Persada, 24

16. Gunawan, A. D., \& Muhadar, N. A. (1997). Supervisory Sanctions against Children in Conflict with the Law.

17. National Narcotics Agency Performance Report 2018, 16

18. Ibid., p. 31

19. Ibid., p. 32

20. Sukarno, A. (2010). Filsafat Hukum, Dari Rekonstruksi Sabda Manusia dan Pengetahuan Hingga Keadilan dan Kebenaran, Makassar: Pustaka Refleksi, 70

21. Suhardin, Y. (2009). Fenomena Mengabaikan Keadilan dalam Penegakan Hukum. Mimbar Hukum-Fakultas Hukum Universitas Gadjah Mada, 21(2), 341-354.

22. Andi, S., \& Nur, A. (2016). Hukum Pidana, Makassar: Pustaka Pena Press, 3

23. Nur, A. (2016). Nilai Keadilan Terhadap Jaminan Kompensasi Bagi Korban Kejahatan (Sebuah Kajian Filospfis - Normatif), Makassar: Pustaka Pena Press, 10

24. Interview with Imam. (2019). (Head of the National Narcotics Agency, Baddoka Makassar) on September 20.

25. Interview with Faisah. (2019). (members of the National Narcotics Agency), on November 24,

26. Ibid. 